\title{
Can Xenobiotics Alter the Sex Ratio of Crocodilians in the Wild?
}

\author{
Satomi Kohno
}

Aquatic Toxicology Laboratory, Department of Biological Sciences, Saint Cloud State University, St. Cloud, MN, USA

\section{Keywords}

Crocodilians - Temperature-dependent sex determination · Xenobiotics

\begin{abstract}
All crocodilians exhibit temperature-dependent sex determination without sex chromosomes. This temperature dependency can be overridden by exposure to estrogen via estrogen receptor 1 . Thus, the sex ratio of crocodilian species is vulnerable to estrogenic xenobiotics. Multiple investigations of the mechanism and effects of xenobiotics in crocodilian species have been conducted since the early 1990s. This review focuses on the impact of xenobiotics on sex determination rather than gonadal functions in crocodilians. The thermosensitive and estrogen-sensitive periods that commit the bipotential gonad to develop as an ovary end by stages 24.5 and 25.3 , respectively. In contrast, it is ambiguous when the estrogen-sensitive stage begins for ovarian development, although the thermosensitive period for ovarian development initiates around developmental stage 15 at an extreme female-producing temperature of $30^{\circ} \mathrm{C}$. To accurately assess the effect of xenoestrogens on sex ratio in crocodilians, it is critical to collect eggs before the sex-determining period and to incubate them under precisely controlled temperatures. A well-studied system of xenobiotic ef-
\end{abstract}

fects on crocodilians is Lake Apopka (FL, USA), an EPA superfund clean-up site heavily contaminated with Dieldrin, Endrin, and $p, p^{\prime}$-DDE. The sum of estimated estrogenicity of xenobiotics measured in Lake Apopka was insufficient to activate the estrogen receptor 1 of Alligator mississippiensis, which is an essential receptor to induce ovarian development. Although juvenile A. mississippiensis showed gonadal alterations in sex hormone production and histology, the environmentally relevant concentration of xenobiotics in Lake Apopka was unlikely to alter the sex ratio of $A$. mississippiensis. Experimental exposure to xenobiotics such as 17a-ethynylestradiol, $p, p^{\prime}$-dichlorodiphenyldichloroethylene, and 2,3,7,8-tetrachlorodibenzodioxin at environmentally relevant concentrations in ovo induced more female offspring in A. mississippiensis as compared with the control group. Bisphenol-A, atrazine, 2,4-dichlorophenoxyacetic acid, endosulfan, and Corexit did not alter the sex ratio of A. mississippiensis or Caiman latirostris under the tested conditions. Egg-incubation temperature has pronounced effects on estrogen sensitivity in crocodilian sex determination. Therefore, crocodilians are vulnerable to xenobiotic contamination and climate change in the wild. It is vital to further investigate the detailed mechanism and effects of environmental xenobiotics in crocodilian sex determination to mitigate their effect on sex ratio and conserve this ancient lineage.

(c) 2021 S. Karger AG, Base karger@karger.com www.karger.com/sxd (c) 2021 S. Karger AG, Base

Karger'
Correspondence to:

Satomi Kohno, skohno@stcloudstate.edu 
The recognition of adverse effects on animal reproductive physiology caused by xenoestrogens, environmental estrogens, and endocrine disruptors can be traced back to 1992 [Bern, 1992] and maybe even earlier studies. After 3 decades of study, it is essential to evaluate the long-term non-lethal effects of xenobiotics to gain a more complete assessment of the environmental impact of these compounds.

Late Dr. Louis J. Guillette Jr. initiated investigations into xenobiotic effects on crocodilian species in the early 1990s [McCoy et al., 2016] in response to reports that juvenile populations of Alligator mississippiensis had declined in Lake Apopka (FL, USA) in the 1980s [Woodward et al., 1993]. The population decline in Lake Apopka was negatively associated with pesticide contamination, such as dicofol, containing 15\% DDT and its metabolites, DDE [Clark, 1990]. Juvenile A. mississippiensis captured in Lake Apopka showed abnormalities in gonadal histology and sex steroid concentration in plasma compared with reference lakes in Florida [Guillette et al., 1994]. Pesticide contamination was identified as the most reasonable explanation for the population decline and gonadal alterations of A. mississippiensis. Guillette and colleagues identified higher concentrations of $17 \beta$-estradiol $\left(E_{2}\right)$ in juvenile females and lower concentrations of testosterone in juvenile males caught in Lake Apopka than at a reference site [Guillette et al., 1994]. Polyovular follicles and polynuclear oocytes in the ovary and bar-shaped structures in the testis were also identified selectively in Lake Apopka alligators [Guillette et al., 1994].

In Lake Apopka, smaller external genitalia associated with lower concentrations of plasma testosterone were common in juvenile A. mississippiensis compared to a population in the reference lake [Guillette et al., 1996]. These characteristics were associated with pesticide contaminants such as Dieldrin, Endrin, and $p, p^{\prime}$-DDE in the plasma of juvenile A. mississippiensis [Guillette et al., $1999 \mathrm{a}, \mathrm{b}]$. The lower concentrations of plasma testosterone in Lake Apopka juvenile A. mississippiensis were concerning as testosterone plays an essential role in the development of external genitalia in crocodilians [Forbes, 1939].

However, it is challenging to prove that the noted association between altered reproductive systems and plasma hormone concentrations in wildlife were causally linked to xenoestrogen pollution due to the abundance of other environmental factors. Hence, there is a need to provide more supportive evidence under controlled conditions to understand the mechanisms by which the observed associations may alter reproductive biology in crocodilians. Furthermore, there is a need for additional investigations into the effects of observed environmental xenobiotics at realistic concentrations on sex determination in crocodilians. This review focuses on sex determination rather than gonadal functions in crocodilians [see Tavalieri et al., 2020 for a review on gonadal functions].

\section{Temperature-Dependent Sex Determination in Crocodilians}

All crocodilians exhibit temperature-dependent sex determination (TSD) without sex chromosomes. Low and high temperatures induce ovarian development, while intermediate temperature induces testicular development. This pattern is called the female-male-female (FMF) or TSD-II pattern [Valenzuela et al., 2004]. TSD-II contains transitional ranges, one F-M and one M-F, with their corresponding lower and higher pivotal temperatures at 32 or $34^{\circ} \mathrm{C}$ that produce a 50:50 sex ratio in A. mississippiensis [Deeming, 2004]. These reaction norms are similar among crocodilians, differing by $3^{\circ} \mathrm{C}$ among species [Deeming, 2004], including A. mississippiensis [Ferguson and Joanen, 1982; Lang and Andrews, 1994].

To clarify the precise thermosensitive period (the window of time when the bipotential gonad commits to becoming an ovary or a testis), temperature shifting experiments are useful. A single shift experiment changes the incubation temperature of the eggs from a male-producing temperature (MPT) to a female-producing temperature (FPT), or FPT-MPT. In a double shift experiment, the temperature is changed twice, starting from MPT, changing to FPT, and changing again to MPT or vice versa. All developmental stages in this review refer to one publication [Ferguson, 1985]. Using single shift experiments starting at 30 or $34^{\circ} \mathrm{C}$, the thermosensitive period was estimated to span days $14-21$ or $28-35$ of incubation, respectively [Ferguson and Joanen, 1983], which are calculated to represent developmental stages $13.0-16.8$ and $21.3-23.4$ by a mathematical model [Kohno and Guillette, 2013]. In another single shift study starting at 31 or $33^{\circ} \mathrm{C}$, the thermosensitive period spanned stage $20-23$ or $21.5-24.5$, respectively [Lang and Andrews, 1994]. The thermosensitive period for testicular commitment overlapped between the 2 studies (developmental stage 21.3-23.4 and 21.5-24.5), whereas sensitivity to $\mathrm{E}_{2}$, the corresponding induction of ovarian development, ended by around developmental stage 25.3 [Kohno et al., 2020]. 
In a double-shift study $\left(30-33-30^{\circ} \mathrm{C}\right)$, a 7 -days pulse at $33^{\circ} \mathrm{C}$ (MPT) was insufficient to completely change the sex ratio [Deeming and Ferguson, 1988]. Another double shift study using $31-33-31^{\circ} \mathrm{C}$ and $33-31-33^{\circ} \mathrm{C}$ revealed that testicular and ovarian development required a 15 days pulse at $33^{\circ} \mathrm{C}(\mathrm{MPT})$ and 20 -days pulse at $31^{\circ} \mathrm{C}$ (FPT), respectively [Lang and Andrews, 1994]. Another study indicated that 18 days of incubation at $30^{\circ} \mathrm{C}$ from developmental stages 9-19 were sufficient to induce a complete shift from testicular development at $32.6^{\circ} \mathrm{C}$ to ovarian development [McCoy et al., 2015]. Developmental stages 15-19 are critical periods for ovarian differentiation [McCoy et al., 2015]. It is consistent with requiring a longer duration for ovarian development, but the timing is variable and may be related to the feminizing potency of 30 and $31^{\circ} \mathrm{C}$. A constant egg incubation at $34^{\circ} \mathrm{C}$ produced $100 \%$ males in one study [Ferguson and Joanen, 1983], whereas it produced 35\% males in another study [Lang and Andrews, 1994]. A constant egg incubation at $32.6^{\circ} \mathrm{C}$ produced $96-97 \%$ males in another study [McCoy et al., 2015]. However, a 15-days pulse of 33 or $34^{\circ} \mathrm{C} \mathrm{ex}$ posure produced 55 or $100 \%$ males in a double shift study (30-33 or $34-30^{\circ} \mathrm{C}$ ), respectively [Lang and Andrews, 1994]. A mismatch in the sex ratio with egg incubation at $34^{\circ} \mathrm{C}$ between these studies may reflect differences in incubation conditions such as a history of incubation temperature, humidity, gas exchange, or population differences.

Estrogen sensitivity peaked at developmental stage 22 at $30^{\circ} \mathrm{C}$ based on mRNA abundance of estrogen receptor 1 [Williams et al., 2018]. These result highlight that the beginning of $\mathrm{E}_{2}$ sensitivity to induce ovarian development needs to be investigated. Precisely identifying the estrogen-sensitive stage may provide valuable information to inform agricultural practices associated with the timing of pesticide application to minimize the potential impact on the sex ratio of wild populations of crocodilians. The temperature dependency in reptile sex determination can be overridden by estrogen exposure in TSD species [Crews et al., 1991]. However, it is not clear when the embryo is sensitive to estrogen signals to develop ovaries. Our current assumption is that the estrogen-sensitive period may coincide with the thermosensitive period, although there is currently a paucity of clear evidence in crocodilians. Our previous study showed that eggs were no longer sensitive to $E_{2}$ by stage 25.3 when receiving an $\mathrm{E}_{2}$ dose of $0.5 \mu \mathrm{g} / \mathrm{g}$ egg [Kohno et al., 2020], estimated at 43 days of egg incubation at $33.5^{\circ} \mathrm{C}$ [Kohno and Guillette, 2013]. This developmental stage represents the end of the estrogen-sensitive period and concurs with the end of the

Can Xenobiotics Alter the Sex Ratio of Crocodilians in the Wild? thermosensitive period at a FPT. The temperature value and duration of exposure are also important for crocodilian sex determination [Lang and Andrews, 1994].

\section{Estrogen Dose and Temperature for Ovarian Development}

Based on re-analysis using a non-linear regression model of dose-response data for $\mathrm{E}_{2}$ and ovarian induction in a previous publication [Kohno et al., 2015], a half-maximal effective concentration of $E_{2}$ to induce females at $33.5^{\circ} \mathrm{C}$ MPT in A. mississippiensis was 0.0388 ppm (0.142 $\mu \mathrm{M})$. In that study, eggs were collected from 7 clutches at an average developmental stage of 16.3 and were incubated at $30^{\circ} \mathrm{C}$ until developmental stage 19 [Kohno et al., 2015]. In another experiment, exposure to 0.014, 0.14, 1.4 , or $14 \mathrm{ppm}(0.051-51 \mu \mathrm{M}) \mathrm{E}_{2}$ at developmental stage 21 induced $100 \%$ females at $33^{\circ} \mathrm{C}$ in A. mississippiensis; however, there was no description of the developmental stage when eggs were collected [Spiteri et al., 1999].

In the broad-snouted caiman, Caiman latirostris, exposure to $1.4 \mathrm{ppm}(5.1 \mu \mathrm{M}) \mathrm{E}_{2}$ at $33^{\circ} \mathrm{C}$ induced $100 \% \mathrm{fe}-$ male offspring, but not at $0.014 \mathrm{ppm}$ [Stoker et al., 2003]. In this experiment, eggs were collected shortly after oviposition, which could be earlier than developmental stage 3 [Stoker et al., 2003]. Thus, these differing results may be associated with either biological difference among species or with differences in the incubation temperature experienced before the onset of the laboratory experiments.

Temperature also plays an essential role in estrogen sensitivity in the red-eared slider turtle [Wibbels et al., 1991]. A detailed study on estrogen sensitivity and temperature has not been conducted on crocodilians. If temperature enhances the estrogenic signals in crocodilians, an environmentally relevant concentration of estrogenic xenobiotics may have more potency to induce ovarian development as global climate change is likely to increase mean environmental temperatures and aquatic pollution due to enhanced precipitation events and associated runoff.

\section{Effects of Environmental Xenobiotics on Sex Determination}

Several investigations have been published using either field studies or controlled laboratory experiments to reveal the effects of environmental xenobiotics on sex determination in 2 crocodilians, A. mississippiensis and 
Table 1. Summary of studies on the effects of xenobiotics on crocodilian sex determination

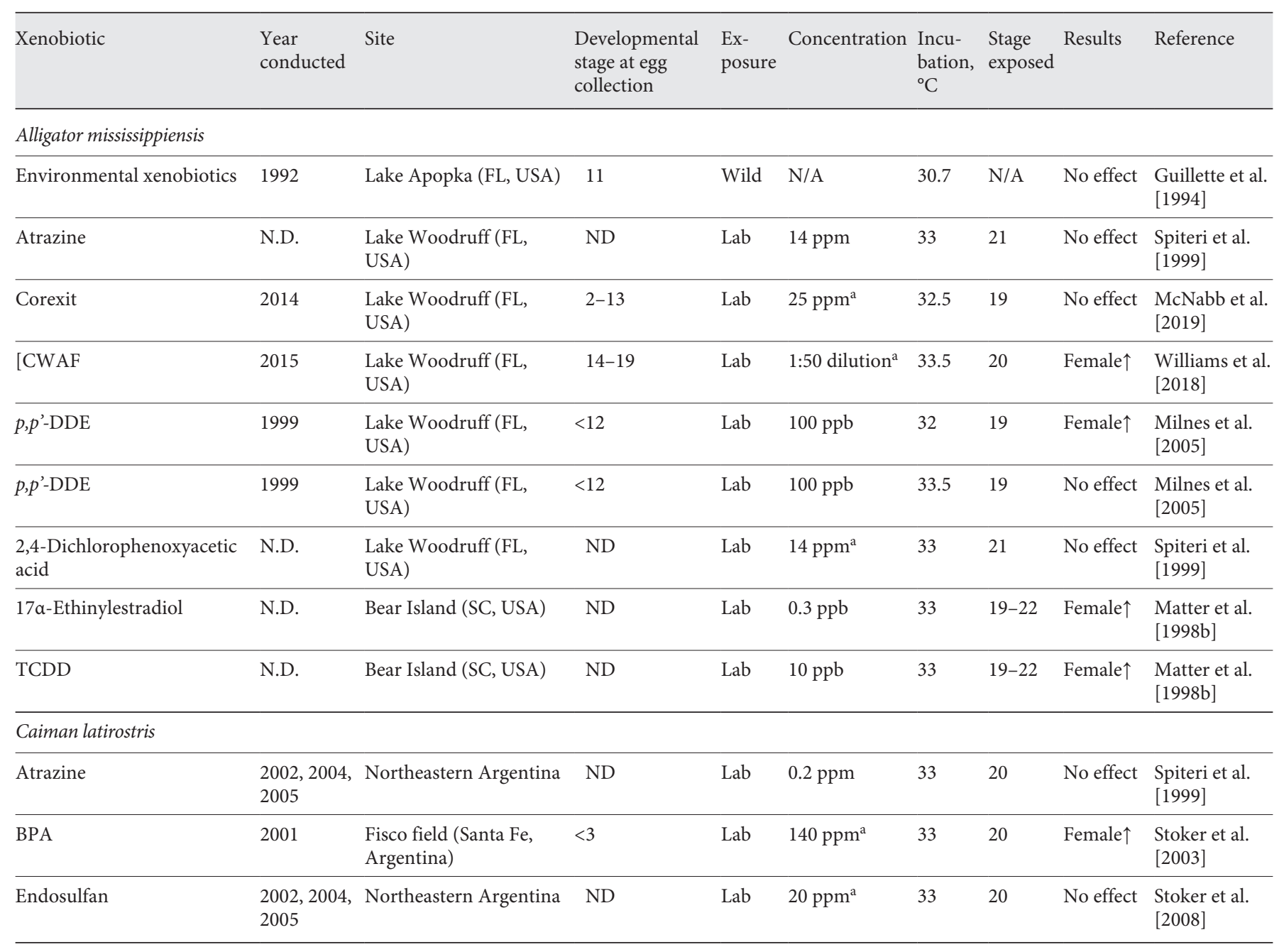

${ }^{a}$ Concentration not environmentally relevant.

C. latirostris (Table 1). This section discusses the potential impact of xenobiotics at environmentally realistic concentration on sex determination in crocodilians.

\section{Alligator mississippiensis}

\section{Lake Apopka}

In the initial study of Dr. Guillette and colleagues, $A$. mississippiensis eggs were collected from Lake Apopka and Lake Woodruff in 1992. The average age of eggs was 12 days after oviposition [Guillette et al., 1994], which was equivalent to developmental stage 11 [Ferguson, 1987; Kohno and Guillette, 2013]. Eggs from both lakes were incubated at $30.7 \pm 0.4^{\circ} \mathrm{C}$. Hatched animals were histologically sexed at 6 months of age [Guillette et al., 1994]. Site differences between Lake Apopka and Lake Wood- ruff did not significantly affect the sex ratio of hatched alligators ( $p=0.5422$ in $\chi^{2}$ test; 69 and 59\% females, respectively) at $30.7^{\circ} \mathrm{C}$ [Guillette et al., 1994]. However, the temperature control of this study may not have been reliable as too many males were obtained at $30.7^{\circ} \mathrm{C}$ from the reference site, Lake Woodruff. At this temperature, it is expected that a $100 \%$ female sex ratio is obtained [Lang and Andrews, 1994]. However, the duration of exposure at this temperature must be $>18$ days and must begin at an early developmental stage of egg incubation at FPT to induce $100 \%$ ovaries [McCoy et al., 2015]. This was not the case in the Lake Apopka study with a 12 day mean egg incubation start day [Guillette et al., 1994]. In Lake Apop$\mathrm{ka}$, higher concentrations of total DDTs in alligator eggs were detected at $3.9 \mathrm{ppm}$, but it was not associated with 
reduced hatching success in another study in 1985 [Heinz et al., 1991]. Therefore, environmental xenobiotics in Lake Apopka were strong enough to be associated with endocrine alterations, but it did not associate with the sex ratio obtained at the $\mathrm{FPT} 30.7^{\circ} \mathrm{C}$.

\section{Atrazine}

Atrazine is a systemic herbicide and was detected at a range of 0.8-76.8 ppb in North America surface water [Cipoletti et al., 2019]. Atrazine can increase aromatase activity in A. mississippiensis [Crain et al., 1997]. In one study, eggs of $A$. mississippiensis were exposed to atrazine at $0.14,1.4$, and $14 \mathrm{ppm}$ at developmental stage 21 and incubated at 30 or $33^{\circ} \mathrm{C}$. Hatchlings were histologically sexed at 10 days of age [Spiteri et al., 1999]. Atrazine exposure in ovo increased gonadal aromatase activity in 10days old hatchlings [Crain et al., 1997], but it did not affect the sex ratio of 10-days old A. mississippiensis [Spiteri et al., 1999]. Thus, atrazine is unlikely to skew the sex ratio of A. mississippiensis in the wild, whereas it has the potency to alter their gonadal steroidogenesis.

\section{Corexit}

Corexit, an oil dispersant, was extensively used during the Deepwater Horizon catastrophe in 2010 in the Gulf of Mexico. The chemical exhibited estrogenic activities via the estrogen receptor 2 of $A$. mississippiensis at $100 \mathrm{ppm}$ in vitro [McNabb et al., 2019]. However, Corexit estrogenicity was too week to induce ovarian development with exposure at developmental state 19 and a lower pivotal temperature $\left(32^{\circ} \mathrm{C}\right)$ in ovo. Therefore, Corexit itself is unlikely to alter the sex ratio since its environmental concentration is well below the experimental concentration of 100 ppm [Kujawinski et al., 2011].

Corexit 9500-Enhanced Water-Accommodated

Fraction of Crude Oil

During the Deepwater Horizon spill, Corexit was purposefully mixed with crude oil at the spill site to disperse the escaping oil [Kujawinski et al., 2011]. Consequently, to assess the full effect of Corexit, it is necessary to study the environmental mixture of Corexit and crude oil (1:50 dilution of Corexit 9500-enhanced water-accommodated fraction of crude oil, CWAF). This mixture activated transcription via nuclear estrogen receptors of $A$. mississippiensis in a luciferase reporter gene assay in vitro [Williams et al., 2018]. In vitro exposure to this mixture at $33.5^{\circ} \mathrm{C}$ for 16 days beginning at developmental stage 20 altered the profile of gonadal mRNA abundance from a male pattern to a female pattern [Williams et al., 2018].
However, CWAF exposure at an environmentally relevant concentration was not likely to alter the sex ratio of A. mississippiensis, although we do not know how estrogenic component(s) could bio-accumulate and bio-magnify in the environment.

\section{$p, p^{\prime}$-Dichlorodiphenyldichloroethylene (DDE)}

The primary contaminant in Lake Apopka, $p, p^{\prime}-\mathrm{DDE}$, was tested in A. mississippiensis embryos [Milnes et al., 2005]. Eggs were collected before stage 12 ( $<2$ weeks after oviposition) from Lake Woodruff National Wildlife Refuge (FL, USA) in 1999 and exposed to $p, p^{\prime}-\mathrm{DDE}$ at 0.0001 , 0.1 , and $100 \mathrm{ppb}$ at 32 or $33.5^{\circ} \mathrm{C}$ [Milnes et al., 2005]. An exposure to $100 \mathrm{ppb} p, p^{\prime}$-DDE induced more females at $32^{\circ} \mathrm{C}$, although this effect was not observed at $33.5^{\circ} \mathrm{C}$. Exposure to $0.1 \mathrm{ppm} \mathrm{E}_{2}$ produced $100 \%$ females at $32^{\circ} \mathrm{C}$, whereas either exposure to $p, p^{\prime}-\mathrm{DDE}$ or $\mathrm{E}_{2}$ did not affect testosterone concentrations in males and females [Milnes et al., 2005]. However, $100 \mathrm{ppb} p, p^{\prime}-\mathrm{DDE}$ was a 5.6 times higher concentration than measured in plasma of $\mathrm{A}$. mississippiensis [Guillette et al., 1999a]. Total DDT was 3.9 ppm in eggs of A. mississippiensis collected in Lake Apopka in 1985 [Heinz et al., 1991]. In another study, $o, p^{\prime}$-DDE or $p, p^{\prime}$-DDE exposure at $0.1-10 \mathrm{ppb}$ partially induced ovarian development at $33^{\circ} \mathrm{C}$ [Matter et al., 1998b]. These results suggest that temperature enhances the effect of $p, p^{\prime}$-DDE exposure on ovarian induction at environmentally relevant concentrations, and environmental $p, p^{\prime}$-DDE at a pivotal temperature has a potency to alter the sex ratio of crocodilians in the wild.

\section{2,4-Dichlorophenoxyacetic Acid}

2,4-Dichlorophenoxyacetic acid is a systemic herbicide and is found in groundwater at $5.4 \mathrm{ppb}$ in Poland [Buczyńska and Szadkowska-Stańczyk, 2005]. Eggs of A. mississippiensis were exposed to 2,4-dichlorophenoxyacetic acid at $0.14,1.4$, and $14 \mathrm{ppm}$ at developmental stage 21 and incubated at 30 or $33^{\circ} \mathrm{C}$. Hatchlings were histologically sexed at 10 days of age [Spiteri et al., 1999]. 2,4-Dichlorophenoxyacetic acid exposure in ovo did not affect the sex ratio at 10 days of age [Spiteri et al., 1999] and is therefore unlikely to skew the sex ratio of $A$. mississippiensis.

\section{7a-Ethinylestradiol}

$17 \alpha$-Ethynylestradiol $\left(\mathrm{EE}_{2}\right)$ is a synthetic estrogen prescribed as a contraceptive and has been measured at concentrations of 20-78 ppb in wild fish in Canada [Al-Ansari et al., 2010]. At these concentrations it can activate estrogen receptor 1 of A. mississippiensis in $100 \%$ of ex- 
posed eggs [Kohno et al., 2015]. In a series of experiments, exposure to $\mathrm{EE}_{2}$ in ovo at concentrations in the ppb range at $33^{\circ} \mathrm{C}$ induced ovarian development in A. mississippiensis [Matter et al., 1998b]. However, combining $\mathrm{EE}_{2}$ with $p, p^{\prime}$-DDE exposure in ovo suppressed the estrogenicity of $\mathrm{EE}_{2}$ in A. mississippiensis [Matter et al., 1998a], whereas $p, p^{\prime}$-DDE exposure alone induced ovarian development under the same condition [Matter et al., 1998b]. Thus, environmental $\mathrm{EE}_{2}$ would be potent enough to alter the sex ratio in wild population of crocodilians.

\section{2,3,7,8-Tetrachlorodibenzodioxin (TCDD)}

TCDD is a family of isomers known as dibenzo- $p$-dioxins and has been linked to various endocrine-disrupting effects [Diamanti-Kandarakis et al., 2009]. TCDD exposure increased female production in a study in which eggs of $A$. mississippiensis incubated at $33^{\circ} \mathrm{C}$ were exposed to 1-10 ppb of TCDD at developmental stage 19-22 and sex was assessed at day 21 posthatching [Matter et al., 1998b]. Since total PCB concentrations in eggs of $\mathrm{A}$. mississippiensis were $170 \mathrm{ppb}$ at the contaminated sites in 1984 [Heinz et al., 1991], environmental relevant TCDD exposures have the potential to skew the sex ratio of crocodilians.

\section{Caiman latirostris}

C. latirostris also exhibits TSD with a FPT of $30^{\circ} \mathrm{C}$ and a MPT of $33^{\circ} \mathrm{C}$ [Stoker et al., 2003], although the reaction norms and thermosensitive period of TSD have not been fully investigated in this species.

\section{Atrazine}

An exposure to atrazine at $0.2 \mathrm{ppm}$ at developmental stage 20 did not induce ovarian development at $33^{\circ} \mathrm{C}$ in C. latirostris, although it decreased the concentration of plasma testosterone at $30^{\circ} \mathrm{C}$ [Stoker et al., 2008]. Atrazine at the experimental concentration did not alter the sex ratio in C. latirostris.

\section{Bisphenol-A}

Bisphenol-A (BPA) is an organic synthetic compound used in polycarbonate plastics, epoxy resins, and dental materials and has a weak estrogenic activity [Vom Saal et al., 2012]. Eggs of C. latirostris were collected before the egg membrane attached to the eggshell $(<$ developmental stage 3) [Stoker et al., 2003]. Exposure of C. latirostris to $140 \mathrm{ppm}$ BPA, a known estrogenic contaminant, at $33^{\circ} \mathrm{C}$ induced ovarian development, but the histology of BPAinduced ovaries was disorganized [Stoker et al., 2003]. Although exposure to $14 \mathrm{ppm} \mathrm{BPA}$ at $33^{\circ} \mathrm{C}$ did not induce ovarian development, disorganized testicular histology was identified as an outcome of exposure [Stoker et al., 2003]. Maximum environmental concentrations of BPA were measured at $97.8,182$, and $8.44 \mathrm{ppb}$ in the surface water, sewage effluent, and sediment in a study conducted in Germany [Fromme et al., 2002]. In the Laurentian Great Lake tributaries, the highest BPA concentration recorded was $380 \mathrm{ppb}$ in the sediment [Elliott et al., 2017]. BPA in the biological specimens ranged from 0.2 to 13,000 ppb [Li et al., 2012]. Therefore, environmental BPA is unlikely to induce ovarian development at MPT, although the temperature and timing of exposure might alter the estrogenic potential of BPA in crocodilians.

\section{Endosulfan}

Endosulfan is an organochlorine insecticide, a potential endocrine disruptor, with measured environmental concentrations ranging from 0.015 to $0.129 \mathrm{ppb}$ in water and sediment samples collected in Argentina [Stoker et al., 2008]. An exposure to endosulfan at $0.02,2$, and 20 ppm at developmental stage 20 did not alter the sex ratio in C. latirostris at either 30 or $33^{\circ} \mathrm{C}$ egg incubation, although testosterone concentrations decreased after exposure to endosulfan at 2 and $20 \mathrm{ppm}$ at $30^{\circ} \mathrm{C}$ [Stoker et al., 2008]. Therefore, endosulfan is unlikely to alter the sex ratio in wild crocodilians.

\section{Conclusion}

Research to assess xenobiotics present in crocodilian eggs remains scarce. It is imperative to analyze the xenobiotics in the eggs to assess their effects on sex determination in crocodilians at the pivotal temperatures. Further investigation into the basic science of the sex determination mechanisms, contaminant burdens, and their effects on the sex determination of crocodilians are also required to maintain crocodilian populations. Enhanced understanding of the temporal and thermal windows of sensitivity to xenoestrogens might provide tools for conservation biologists to mitigate the effects of pesticide use.

Several environmental xenobiotics have the potential to skew the sex ratio of crocodilian populations in the wild. However, the complexity and plasticity of their sex determination currently prevent a comprehensive understanding of the effects of environmental xenobiotics on sex ratios in crocodilians. As the sensitivity of sex determination is driven by temperature and timing, a multitude of environmental and anthropogenic factors can collude to alter sex ratios. The influence of contributing fac- 
tors is further complicated by the effects of climate change, genetic variation, and variable history of exposure to pollutants in native crocodilian habitats. Without additional research to create a comprehensive understanding of the effects of xenoestrogens on crocodilian sex determination, conservation biologists will be poorly equipped to protect crocodilian species from population decline with unknown consequences for the ecological balance in the swamp.

\section{Acknowledgments}

To the late Dr. Louis J. Guillette, Jr, I was honored to be a part of the research group that his legacy has created and to have had the chance to learn from him. I am grateful to the Florida Fish and
Wildlife Conservation Commission and Kennedy Space Center Integrated Mission Support Service to assist with egg collection for a long time, which is no small task. Lastly, I thank Dr. Heiko L. Schoenfuss at St. Cloud State University for his critical reading and comments on this manuscript.

\section{Conflict of Interest Statement}

The author has no conflicts of interest to declare.

\section{Funding Sources}

This work was supported by the Faculty Improvement Grant, St. Cloud State University (grant number 13398375).

\section{References}

Al-Ansari AM, Saleem A, Kimpe LE, Sherry JP, McMaster ME, Trudeau VL, et al. Bioaccumulation of the pharmaceutical 17 a-ethinylestradiol in shorthead redhorse suckers (Moxostoma macrolepidotum) from the St. Clair River, Canada. Environ Pollut. 2010;158:2566-71.

Bern AH. Statement from the work session on chemically-induced alterations in sexual development: the wildlife/human connection. In: Colborn T, Clement $\mathrm{C}$, editors. Chemically-Induced Alterations in Sexual and Functional Development: The Wildlife/Human Connection. Princeton, NJ: Princeton Scientific Publishing Co.; 1992. p. 1-8.

Buczyńska A, Szadkowska-Stańczyk I. Identification of health hazards to rural population living near pesticide dump sites in Poland. Int $J$ Occup Med Environ Health. 2005;18(4):3319.

Cipoletti N, Jorgenson ZG, Banda JA, Hummel SL, Kohno S, Schoenfuss HL. Land use contributions to adverse biological effects in a complex agricultural and urban watershed: A case study of the Maumee River. Environ Toxicol Chem. 2019;38(5):1035-51.

Clark DR. Dicofol (Kelthane) as an environmental contaminant: a review. Washington, DC: U.S. Fish and Wildlife Service; 1990.

Crain DA, Guillette LJ, Rooney AA, Pickford DB. Alterations in steroidogenesis in alligators (Alligator mississippiensis) exposed naturally and experimentally to environmental contaminants. Environ Health Perspect. 1997; 105(5):528-33.

Crews D, Bull JJ, Wibbels T. Estrogen and sex reversal in turtles: A dose-dependent phenomenon. Gen Comp Endocrinol. 1991;81(3): 357-64.

Deeming DC. Prevalence of TSD in Crocolilians. In: Valenzuela NM, Lance VA, editors. Temperature-Dependent Sex Determination in
Vertebrates. Washington, DC: Smithonian Institution; 2004. p. 33-41.

Deeming DC, Ferguson MW. Environmental regulation of sex determination in reptiles. Philos Trans R Soc Lond, B, Biol Sci. 1988; 322(1208):19-39.

Diamanti-Kandarakis E, Bourguignon JP, Giudice LC, Hauser R, Prins GS, Soto AM, et al. Endocrine-disrupting chemicals: An endocrine society scientific statement. Endocr Rev. 2009;30(4):293-342.

Elliott SM, Brigham ME, Lee KE, Banda JA, Choy SJ, Gefell DJ, et al. Contaminants of emerging concern in tributaries to the Laurentian Great Lakes: I. Patterns of occurrence. PLoS One. 2017;12(9):e0182868.

Ferguson MWJ. Reproductive biology and embryology of the crocodilians. In: Gans C, Billett FS, Maderson PFA, editors. Biology of the Reptilia: Development. New York, NY: J. Wiley and Sons; 1985. p. 329-491.

Ferguson MWJ. Post-laying stages of embryonic development for crocodilians. In: Webb GJW, Manolis SC, Whitehead PJ, editors. Wildlife management : Crocodiles and alligators. Sidney: Surrey Beatty \& Sons; 1987. p. 427-44.

Ferguson MW, Joanen T. Temperature of egg incubation determines sex in Alligator mississippiensis. Nature. 1982;296(5860):8503.

Ferguson MWJ, Joanen T. Temperature-dependent sex determination in Alligator mississippiensis. J Zool. 1983;200:143-77.

Forbes TR. Studies on the reproductive system of the alligator. V. The effects of injections of testosterone propionate in immature alligators. Anat Rec. 1939;75(1):51-7.

Fromme H, Küchler T, Otto T, Pilz K, Müller J, Wenzel A. Occurrence of phthalates and bisphenol $\mathrm{A}$ and $\mathrm{F}$ in the environment. Water Res. 2002;36(6):1429-38.
Guillette LJ, Gross TS, Masson GR, Matter JM, Percival HF, Woodward AR. Developmental abnormalities of the gonad and abnormal sex hormone concentrations in juvenile alligators from contaminated and control lakes in Florida. Environ Health Perspect. 1994;102(8): 680-8.

Guillette LJ, Pickford DB, Crain DA, Rooney AA, Percival HF. Reduction in penis size and plasma testosterone concentrations in juvenile alligators living in a contaminated environment. Gen Comp Endocrinol. 1996;101(1):32-42.

Guillette LJ, Jr., Brock JW, Rooney AA, Woodward AR. Serum concentrations of various environmental contaminants and their relationship to sex steroid concentrations and phallus size in juvenile American alligators. Arch Environ Contam Toxicol. 1999a;36(4): $447-55$.

Guillette LJ, Woodward AR, Crain DA, Pickford DB, Rooney AA, Percival HF. Plasma steroid concentrations and male phallus size in juvenile alligators from seven Florida lakes. Gen Comp Endocrinol. 1999b;116(3):356-72.

Heinz GH, Percival HF, Jennings ML. Contaminants in American alligator eggs from Lake Apopka, Lake Griffin, and Lake Okeechobee, Florida. Environ Monit Assess. 1991;16(3): 277-85.

Kohno S, Guillette LJJ. Endocrine disruption and reptiles: using the unique attributes of temperature- dependent sex determination to assess impacts. In: Matthiessen P, editor. Endocrine Disrupters. Hoboken, NJ: John Wiley \& Sons; 2013. p. 245-71.

Kohno S, Bernhard MC, Katsu Y, Zhu J, Bryan TA, Doheny BM, et al. Estrogen receptor 1 (ESR1; ER $\alpha$ ), not ESR2 (ER $\beta)$, modulates estrogen-induced sex reversal in the American alligator, a species with temperature-dependent sex determination. Endocrinology. 2015; 156:1887-99. 
Kohno S, Vang D, Ang E, Brunell AM, Lowers RH, Schoenfuss HL. Estrogen-induced ovarian development is time-limited during the temperature-dependent sex determination of the American alligator. Gen Comp Endocrinol. 2020;291:113397.

Kujawinski EB, Kido Soule MC, Valentine DL, Boysen AK, Longnecker K, Redmond MC. Fate of dispersants associated with the Deepwater Horizon oil spill. Environ Sci Technol. 2011;45(4):1298-306.

Lang JW, Andrews HV. Temperature-dependent sex determination in crocodilians. J Exp Zool. 1994;270(1):28-44.

Li X, Pham HT, Janesick AS, Blumberg B. Triflumizole is an obesogen in mice that acts through peroxisome proliferator activated receptor gamma (PPAR gamma). Environ Health Perspect. 2012;120:1720-6.

Matter JM, Crain DA, McMurry CS, Pickford DB, Rainwater TR, Reynolds KD, et al. Effects of endocrine-disrupting contaminants in reptiles: Alligators. In: Kendall R, Dickerson R, Giesy J, Suk W, editors. Principles and Processes for Evaluating Endocrine Disruption in Wildlife. Pensacola, FL: SETAC Press; 1998a. p. 267-89.

Matter JM, McMurry CS, Anthony AB, Dickerson RL. Development and implementation of endocrine biomarkers of exposure and effects in American alligators (Alligator mississippiensis). Chemosphere. 1998b;37(9-12):190514.
McCoy JA, Parrott BB, Rainwater TR, Wilkinson PM, Guillette Jr. LJ: Incubation history prior to the canonical thermosensitive period determines sex in the American alligator. Reproduction. 2015;150:279-87.

McCoy KA, Roark AM, Boggs ASP, Bowden JA, Cruze L, Edwards TM, et al. Integrative and comparative reproductive biology: From alligators to xenobiotics. Gen Comp Endocrinol. 2016;238:23-31.

McNabb NA, Bernhard MC, Brunell A, Russell |, Lowers H, Katsu Y, et al. Oil dispersant Corexit 9500 is weakly estrogenic, but does not skew the sex ratio in Alligator mississippiensis. J Appl Toxicol. 2019:1-12.

Milnes MR, Bryan TA, Medina JG, Gunderson MP, Guillette Jr. LJ: Developmental alterations as a result of in ovo exposure to the pesticide metabolite p,p'-DDE in Alligator mississippiensis. Gen Comp Endocrinol. 2005; 144:257-63.

Spiteri ID, Guillette LJ, Crain DA. The functional and structural observations of the neonatal reproductive system of alligators exposed in ovo to atrazine, 2,4-D, or estradiol. Toxicol Ind Health. 1999;15:181-6.

Stoker C, Rey F, Rodriguez H, Ramos JG, Sirosky P, Larriera A, et al. Sex reversal effects on Caiman latirostris exposed to environmentally relevant doses of the xenoestrogen bisphenol A. Gen Comp Endocrinol. 2003;133(3):28796.
Stoker C, Beldoménico PM, Bosquiazzo VL, Zayas MA, Rey F, Rodríguez H, et al. Developmental exposure to endocrine disruptor chemicals alters follicular dynamics and steroid levels in Caiman latirostris. Gen Comp Endocrinol. 2008;156(3):603-12.

Tavalieri YE, Galoppo GH, Canesini G, Luque EH, Muñoz-de-Toro MM. Effects of agricultural pesticides on the reproductive system of aquatic wildlife species, with crocodilians as sentinel species. Mol Cell Endocrinol. 2020; 518:110918.

Valenzuela N, Lance VA, Valenzuela N, Lance VA. Temperature-Dependent Sex Determination in Vertebrates. Washington, DC: Smithsonian Books; 2004

Vom Saal FS, Nagel SC, Coe BL, Angle BM, Taylor JA. The estrogenic endocrine disrupting chemical bisphenol A (BPA) and obesity. Mol Cell Endocrinol. 2012;354(1-2):74-84.

Wibbels T, Bull JJ, Crews D. Synergism between temperature and estradiol: A common pathway in turtle sex determination? J Exp Zool. 1991;260(1):130-4.

Williams CE, McNabb NA, Brunell A, Lowers RH, Katsu Y, Spyropoulos DD, et al. Feminizing effects of exposure to Corexit-enhanced wateraccommodated fraction of crude oil in vitro on sex determination in Alligator mississippiensis. Gen Comp Endocrinol. 2018;265:46-55.

Woodward AR, Percival HF, Jennings ML, Moore CT. Low clutch viability of American alligators on Lake Apopka. Fl Sci. 1993;56:52-63. 